\title{
Endoparasitose em bovinos
}

Eloise Bertoglio, Patrícia Martinelli, Ana Raquel Marsiglio Ferronato, Alessandra Marques Pavlak, Tainá Secco, Deise Luiza Mahl, Morgana Karin Pierozan, Thiago de Souza Rosés, Elisandra Andreia Urio, Daniela dos Santos de Oliveira

Instituto de Desenvolvimento Educacional do Alto Uruguai (Faculdade Ideau), Getúlio Vargas, RS, Brasil

*Autor correspondente

e-mail: eloise_bertoglio@hotmail.com

\section{Resumo}

A parasitologia é dividida em ectoparasitas e endoparasitas, sendo que os ectoparasitas são aqueles que têm contato com a pele dos hospedeiros e que vivem na superfície ou em cavidades dos mesmos, os artrópodes, como bernes, carrapatos e pulgas. Os endoparasitas são aqueles que se alimentam das vitaminas, proteínas, açúcares e sais minerais ingeridos pelos animais também chamados de hospedeiros. Os vermes concorrem com o hospedeiro e, dependendo da quantidade e da falta de controle, podem retardar muito o crescimento e o desenvolvimento do animal. Alguns vermes são sugadores, ou seja, tiram o sangue do hospedeiro para se alimentarem, fazendo com que principalmente os animais mais jovens, sem resistência, como os bezerros, apresentem uma forte anemia. 0 objetivo deste trabalho foi realizar a coleta de fezes e identificação de endoparasitas de bovinos de leite através da técnica de Willis Mollay em três propriedades do Rio Grande do Sul, situadas no interior das cidades de Erechim, São Valentim e Tapejara, das quais duas mantinham controle rigoroso, fazendo o uso de anti-helminticos a cada seis meses, e a outra não. Para a realização do trabalho, coletaram-se amostras fecais de 30 vacas leiteiras, dez em cada propriedade. Após as fezes serem coletadas, foram resfriadas e levadas ao Laboratório da Faculdade IDEAU, em Getúlio Vargas, para serem avaliadas ao microscópio; essa técnica é utilizada na pesquisa de ovos leves de helmintos. No laboratório, foram separadas e pesadas apenas cinco gramas de fezes de cada animal em um bequer e, posteriormente, acrescentou-se $10 \mathrm{ml}$ de $\mathrm{NaCl}$, utilizando o bastão de vidro para a mistura dos produtos. Em seguida, usouse o frasco de borrel com duas gases abertas para filtrar a mistura, completando o mesmo com solução de $\mathrm{NaCl}$ até a borda; a lâmina foi sobreposta no frasco para ficar em contato com o líquido misturado durante 5 minutos, para que os ovos ou oocistos flutuassem até a lâmina e se fixassem nela. Após os 5 minutos, retirou-se a lâmina do frasco, pingou-se uma gota de lugol, colocou-se a lamínula e realizou-se o exame com auxílio de microscópio eletrônico, fazendo varredura de toda a lâmina. Foi possível concluir que de 
trinta vacas leiteiras, apenas seis possuíam endoparasitas, sendo estes semelhantes a Neospora caninun, oocisto de helminto, Trichostrongylidae sp., Fasciola sp. e Capillaria sp. Sendo assim, as propriedades que usam anti-helmínticos mantêm a higiene, possuem boas práticas de manejo, disponibilizam aos animais alimentos adequados e não possuem tanta ocorrência de endoparasitas. Já nas propriedades que não possuem cuidados adequados, os animais acabam apresentando parasitas, o que poderá causar danos aos animais assim como prejuízos em relação à produtividade das vacas leiteiras. 